Науковий вісник НлТУ України Scientific Bulletin of UNFU

https://nv.nltu.edu.ua

https://doi.org/10.15421/40290211

Article received $21.02 .2019 \mathrm{p}$.

Article accepted 28.03.2019 p.

УДК 595.786:591.53(477.42)
ISSN 1994-7836 (print)

ISSN 2519-2477 (online)

$@ \bowtie$ Correspondence author

T. I. Kovtun

igkov@ukr.net

T. І. Ковтун

Житомирський національний агроекологічний університет, м. Житомир, Украӥна

\title{
ТАКСОНОМІЧНИЙ СКЛАД КОРМОВИХ РОСЛИН ГУСЕНІ СОВКОПОДІБНИХ (LEPIDOPTERA: NOCTUOIDEA) В УМОВАХ НАПІВПРИРОДНИХ ЕКОСИСТЕМ ПРИМІСЬКОЇ ЗОНИ МІСТА ЖИТОМИР
}

\begin{abstract}
Унаслідок проведених досліджень зібрано 2154 екземпляри комах, що належать до 125 видів совкоподібних, які належать до 3 родин і 24 підродин. Проаналізовано розподіл гусені совкоподібних у виявлених родинах та підродинах Noctuoidea відносно основних життєвих форм рослин, а також таксономічний склад кормових рослин. Встановлено, що частка хортофагів становить 53 \%. Частка дендрофагів та хорто-дендрофагів $\epsilon$ приблизно однаковою (22 та 25 \% відповідно). Виявлено, що гусінь совкоподібних досліджуваного району трофічно пов'язана зі 105 родинами 3 відділів наземних рослин флори України. З'ясовано, що частка представників відділів папоротеподібних (Polypodiophyta) та голонасінних (Pinophyta) незначна: 5,7 та $1 \%$ відповідно. Кормовими рослинами з відділу Polypodiophyta є представники 6 родин. 3 відділу голонасінних як кормові рослини виявлено представників однієї родини - Ріпасеае. Досліджено, що переважаючу частку кормових рослин виявлених видів совкоподібних становлять покритонасінні рослини (Magnoliophyta) - 93,3 \%. 3 класом однодольних (Liliopsida) облігатно пов'язано 10 видів; 3 дводольними (Magnoliopsida) облігатно пов'язано 45 видів. Найбільшу кількість видів виявлено на представниках родин Rosaceae, Asteraceae та Poaceae (71, 69 та 68 виявлених видів відповідно). Встановлено, що більшість шкідливих видів за харчовою спеціалізацією є хортофільними поліфагами із широкими трофічними зв'язками.
\end{abstract}

Ключові слова: поліфаги; олігофаги; хортофаги; дендрофаги; хорто-дендрофаги; ліхенофаги.

Вступ. Совкоподібні (Lepidoptera: Noctuoidea) $\epsilon$ найбільшою надродиною з ряду лускокрилих. У світовій фауні, за різними підрахунками, нараховується від 40 до 70 тис. видів ноктуід (Matov \& Kononenko, 2012), iз них на кінець 2010 р. в Україні зареєстровано 683 види (Kluchko et al, 2011). Гусінь совок розвивається на представниках всіх класів наземних рослин, а деякі групи - на лишайниках, грибах та водоростях. Низка видів Noctuoidea $є$ небезпечними шкідниками сільського та лісового господарства. Зважаючи на це, розгляд особливостей трофічної спеціалізації фауни совок має важливе практичне значення.

Найповнішими сучасними роботами щодо гусені та трофічних зв'язків Noctuoidea та інших лускокрилих $\epsilon$ зведення та ілюстровані монографії з фауни Свропи (Beck, 1999-2000; Ahola \& Silvonen, 2005, 2008, 2011); Японії (Mutuura et al., 1973; Yamamoto \& Sugi, 1987), Північної Америки (Robinson et al., 2002), Орієнтальної області (Robinson et al., 2001). Відомості щодо екології совкоподібних лускокрилих Європи наведено в 13-томній серії Noctuidae Europaeae (1990-2011). Створено світову базу даних із трофічних зв'язків лускокрилих, включаючи Noctuoidea (Robinson, 1999; Robinson et al., 2010).

Окрім цього, проаналізовано роботи, в яких подано характеристику кормових рослин совок України зага- лом та вивчено трофічні зв'язки гусені совкоподібних деяких регіонів, зокрема Дніпропетровської обл. (Kliuchko, 2006; Kliuchko et al, 2011). Також використано відомості з трофічних зв'язків совкоподібних Росії (Matov \& Kononenko, 2012; Barbarich, 2013, 2015) та Білорусі (Derzhinskii \& Vogulkina, 2017).

Для приміської зони Житомира характерна наявність напівприродних екосистем (тобто порушених людиною біот, що зберігають основні властивості екосистем), в яких відбуваються постаграрні сукцесії. Такі сукцесії супроводжуються інтенсивним лісовідновленням завдяки припиненню розорювання деякої частини полів та зниженню пасовищного навантаження. Це призводить до інтенсивної зміни фітоасоціацій, а отже, і зміни кормових рослин для всіх фітофагів, включаючи i совкоподібних. Тому такі екосистеми є надзвичайно цікавими для дослідження трофічних зв'язків гусені совкоподібних, зокрема таксономічного складу кормових рослин. Адже достатня кормова база є одним із визначальних показників стійкості ентомокомплексу певної екосистеми (Kliuchko et al, 2011).

Отже, мета дослідження - проаналізувати харчову спеціалізацію та таксономічний склад кормових рослин гусені совкоподібних (Lepidoptera: Noctuoidea) в умовах напівприродних екосистем приміської зони Житомира.

Інформація про авторів:

Ковтун Тетяна Ігорівна, канд. с.-г. наук, доцент, кафедра загального лісівництва.

Email: igkov@ukr.net; https://orcid.org/0000-0003-1611-8030

Цитування за ДСту: Ковтун Т. І. Таксономічний склад кормових рослин гусені совкоподібних (Lepidoptera: Noctuoidea) в умовах напівприродних екосистем приміської зони міста Житомир. Науковий вісник НлтУ України. 2019, т. 29, № 2. С. 58-61.

Citation APA: Kovtun, T. І. (2019). Taxonomic composition of host plants of noctuid moth's larvae (Lepidoptera: Noctuoidea) in semi natural ecosystems of Zhytomyr suburban area. Scientific Bulletin of UNFU, 29(2), 58-61. https://doi.org/10.15421/40290211 
Матеріал і методи дослідження. Дослідження проводились в районі села Березівка, Житомирського р-ну, Житомирської обл. впродовж польових сезонів 20112018 рр. Вибрали дві дослідні ділянки, на яких було обладнано постійні пункти обліку нічних метеликів за допомогою світлової пастки. Як джерело світла використовували люмінесцентні лампи потужністю $100 \mathrm{~W}$. Збір комах проводили 2 рази на місяць на кожній ділянці. Комах заморювали етилацетатом. Визначення совкоподібних проводили відповідно до загальноприйнятої міжнародної систематики (Fibiger et al, 2011). Статистичне оброблення результатів виконували за загальноприйнятими методиками з використанням пакетів прикладних комп'ютерних програм Microsoft EXCEL.

Район зборів, що займає площу близько 5 га, розташований на східній околиці Березівки, на відстані 15 км від Житомира. 3 північної і західної сторони ділянка обмежена меліоративними каналами; на південній межі розміщена дубова полезахисна смуга; східною стороною ділянка межує з чагарниковою та низькорослою деревною рослинністю. У північно-східному секторі розташоване частково заболочене багно, заросле осокою (Cárex), вільхою сірою (Alnus incana L.) та малиною (Rubus idaeus L.) Найближчі житлові будівлі розміщені на відстані 500 м від західного кордону ділянки. У південному напрямку на відстані 1,5 км проходить міжнародна траса Київ-Чоп, у цьому ж напрямку на відстані 3 км розташований Березівський гранітний кар'єр. Ділянку використовували впродовж тривалого часу (близько 40 років) як сільськогосподарські угіддя (під пасовище та посіви сільськогосподарських культур). У 1992 р. землю було виділено під індивідуальні городи. Активна діяльність городників тривала впродовж 10 років. 3 початку 2000-х років близько половини наділів не використовують під посадку сільськогосподарських культур, епізодично викошують траву і випасають худобу. Із дикорослих рослин переважають: дерева - вільха cipa (Alnus incana L.), дуб звичайний (Quercus robur L.), береза повисла (Betula pendula L.), яблуня лісова (Malus sylvestris Mill.), сосна звичайна (Pinus sylvestris L.); чагарники - верба козяча (Salix caprea L.), малина (Rubus idaeus L.), бересклет європейський (Euonymus europaeus L.); трав'яні рослини - пирій повзучий (Elymus repens L.), деревій звичайний (Achillea millefolium L.), подорожники (Plantágo) осот польовий (Cirsium arvense L.), кульбаба лікарська (Taraxacum officinale L.), конюшини (Trifolium), лобода смердюча (Chenopodium vulvaria L.), полин звичайний (Artemisia vulgaris L.), злаки (Рoáceae) тощо. Із культурних рослин вирощують переважно городину: картопля (Solanum tuberosum L.), кукурудза звичайна (Zea mays L.), помідор їсівний (Lycopersicon esculentum Mill), буряк звичайний (Beta vulgaris L.), морква посівна (Daucus sativus (Hoffm.) Roehl.), пшениця м'яка (Triticum aestivum L.), жито посівне (Secale cereale L.), овес звичайний (Avena sativa L.), горошок посівний (Vicia sati$v a \mathrm{~L}$.), гарбуз звичайний (Cucurbita pepo L.).

Результати дослідження та їх обговорення. Унаслідок проведених досліджень зібрано 2154 екземпляри комах, що належать до 125 видів совкоподібних, які відповідно до загальноприйнятої міжнародної систематики (Fibiger et al, 2011) належать до 3 родин і 24 підродин. Як зазначено вище, гусінь совок має широкий спектр харчових зв'язків, однак для більшості видів ха- рактерна саме фітофагія - харчування на рослинах. Так, у районі досліджень фітофагами є 123 (98,4 \%) виявлені види (Kovtun, 2018).

Окрім фітофагів, у фауні совок напівприродних екосистем приміської зони Житомира трапляються 2 представники нечисельної групи зі спеціалізованим типом харчування - ліхенофагів. Як відомо, до ліхенофагів належать совки, що розвиваються переважно на плодових тілах деревних лишайників. У фауні досліджуваного району це представники підродини Bryophilinae - Крифія фраудатрикула (Cryphia fraudatricula (Hübner, 1803)) та Крифія жовтувата (Cryphia algae (Fabricius, 1775) (= degener [Denis et Schiffermuller], 1775)), гусінь яких надає перевагу лишайникам роду Parmelia (Matov \& Kononenko, 2012). Причому, якщо C. algae трофічно пов'язана переважно із стовбурними лишайниками листяних порід, то $C$. fraudatricula дотримується змішаної дієти - із додаванням водоростей (Kliuchko et al, 2011).

На початку цього дослідження аналізували трофічні зв'язки фітофагів відносно основних життєвих форм рослин (табл. 1). За цією ознакою совкоподібних району досліджень можна поділити на три групи: хортофаги, що пов'язані із трав'яними рослинами; дендрофаги, харчова спеціалізація яких пов'язана 3 деревними рослинами; хорто-дендрофаги, що характеризуються широкими харчовими зв'язками гусені, яка розвивається на кормових рослинах різних життєвих форм.

Табл. 1. Розподіл фітофагів відносно основних життсвих форм рослин у виявлених родинах та підродинах

\begin{tabular}{|c|c|c|c|c|}
\hline $\begin{array}{c}\text { Родина та } \\
\text { підродина }\end{array}$ & $\begin{array}{c}\text { Кі-сть } \\
\text { видів }\end{array}$ & $\begin{array}{c}\text { Дендрофа- } \\
\text { ги, \% }\end{array}$ & $\begin{array}{c}\text { Хортофа- } \\
\text { ги, \% }\end{array}$ & $\begin{array}{c}\text { Хортоден- } \\
\text { дрофаги, \% }\end{array}$ \\
\hline Noctuidae & 112 & $20(18)$ & $62(55)$ & $30(27)$ \\
\hline Noctuinae & 18 & - & $10(56)$ & $8(44)$ \\
\hline Hadeninae & 26 & $5(19)$ & $11(42)$ & $10(39)$ \\
\hline Xyleninae & 39 & $7(18)$ & $26(67)$ & $6(15)$ \\
\hline Plusiinae & 7 & - & $6(86)$ & $1(14)$ \\
\hline Eustrotiinae & 1 & - & $1(100)$ & - \\
\hline Acronictinae & 8 & $5(63)$ & - & $3(37)$ \\
\hline Psaphidinae & 1 & $1(100)$ & - & - \\
\hline Amphipyrinae & 1 & - & $1(100)$ & - \\
\hline Pantheinae & 1 & $1(100)$ & - & - \\
\hline Dilobinae & 1 & $1(100)$ & - & - \\
\hline Cuculliinae & 1 & - & $1(100)$ & - \\
\hline Condicinae & 2 & - & $1(50)$ & $1(50)$ \\
\hline Heliothinae & 3 & - & $2(67)$ & $1(33)$ \\
\hline Acontiinae & 1 & - & $1(100)$ & - \\
\hline Eriopinae & 1 & - & $1(100)$ & - \\
\hline Metoponiinae & 1 & - & $1(100)$ & - \\
\hline Erebidae & 9 & $5(56)$ & $3(33)$ & $1(11)$ \\
\hline Hypeninae & 2 & - & $1(50)$ & $1(50)$ \\
\hline Erebinae & 4 & $3(75)$ & $1(25)$ & - \\
\hline Scoliopteryginae & 1 & $1(100)$ & - & - \\
\hline Herminiinae & 1 & - & $1(100)$ & - \\
\hline Boletobiinae & 1 & $1(100)$ & - & - \\
\hline Nolidae & 2 & $2(100)$ & - & - \\
\hline Chloephorinae & 2 & $2(100)$ & - & - \\
\hline Bcsoro: & 123 & $27(22)$ & $65(53)$ & $31(25)$ \\
\hline 3ride & & & & \\
\hline
\end{tabular}

Згідно 3 даними табл. 1, більшість виявлених видів совкоподібних досліджуваного району належить до хортофагів - 65 видів (53\%). Частка дендрофагів та хорто-дендрофагів є приблизно однаковою (22 та $25 \%$, відповідно). Варто зазначити, що спеціалізація на основних життєвих формах рослин виражена не тільки на рівні родів і триб, але і на рівні підродин. Так, хортофаги переважають у таких підродинах родини Noctuidae, як Noctuinae, Xyleninae, Plusiinae, Hadeninae. Загалом хортофаги становлять $55 \%$ від виявлених видів Noctui- 
dae. Водночас підродини 3 родин Erebidae та Nolidae представлені переважно видами, що належать до дендрофагів (56 та $100 \%$, відповідно). Привертає увагу достатньо висока частка (25\%) хорто-дендрофагів у фауні совок досліджуваного району. Найчастіше подібна спеціалізація є наслідком широкої поліфагії виду та характерна для таких підродин совок, як Xyleninae, Hadeninae та Noctuinae. Найтиповішими хорто-дендрофагами є представники родів Xylena Ochs., Polia Ochs., Diarsia Hübn. та Cerastis Ochs (Barbarich, 2015). Окрім цього, для деяких представників підродини Xyleninae (Совка золотисто-сіра (Xanthia ocellaris (Borkhausen, 1792)), Совка золотиста малинова (Xanthia icteritia (Hufnagel, 1766)), Совка золотиста подорожникова (Xanthia togata (Esper, 1788)), Совка плоскотіла чорнична (Conistra vaccinii (Linnaeus, 1761)) в ході розвитку відбувається зміна кормових рослин різних життєвих форм (Matov \& Kononenko, 2012).

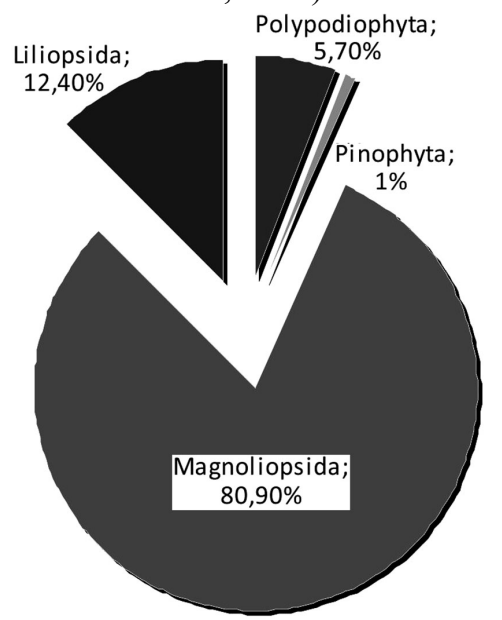

Рисунок. Таксономічний склад кормових рослин гусені совкоподібних в умовах напівприродних екосистем приміської зони Житомира

Отже, виявлене співвідношення хортофагів, дендрофагів та хорто-дендрофагів у фауні досліджуваного району загалом відповідає загальним закономірностям розподілу гусені совок відносно основних життєвих форм рослин. Разом з тим, як особливість, можна відзначити дещо меншу частку дендрофагів та дещо більшу частку хорто-дендрофагів серед виявлених видів. Це, вірогідно, пов'язано з характером рослинності цього району та ступенем його гемеробії.

Наступним етапом роботи був аналіз таксономічного складу кормових рослин гусені совкоподібних (Lepidoptera: Noctuoidea) в умовах напівприродних екосистем приміської зони Житомира (рисунок). Відомо, що гусінь совок розвивається на представниках всіх класів наземних рослин. Встановлено, що гусінь совкоподібних досліджуваного району трофічно пов'язана 3105 родинами 3 відділів наземних рослин флори України.

Як видно 3 рисунка, переважаючу частку кормових рослин виявлених видів совкоподібних становить покритонасінні рослини (Magnoliophyta) - 93,3\%, 3 яких $80,9 \%$ родин належать до класу дводольних (Magnoliopsida) та 12,4 \% - до класу однодольних (Liliopsida). Водночас представники відділів папоротеподібних (Polypodiophyta) та голонасінних (Pinophyta) не $\epsilon$ характерними кормовими рослинами досліджуваних видів совок. Їх частка незначна: 5,7 та 1 \% відповідно. Такі результати збігаються з даними інших досліджень. (Маtov \& Kononenko, 2012; Barbarich, 2015; Derzhinskii \& Vogulkina, 2017).

Кормовими рослинами 3 відділу Polypodiophyta є представники 6 родин. Харчування папоротеподібними характерне для Совки червонуватої пухнастоногої (Callopistria juventina (Stoll, 1782)) 3 підродини Eriopinae. 3 відділу голонасінних як кормові рослини виявлено представників однієї родини - Pinaceae. З'ясовано, що на рослинах родини соснових харчуються 8 видів совкоподібних досліджуваного району. Причому жоден 3 них не є облігатним споживачем хвої. Навіть такий небезпечний шкідник лісового господарства, який дає спалахи масового розмноження в Україні, як Совка соснова (Panolis flammea ([Denis et Schiffermüller], 1775) (= piniperda Panzer, 1786)) може переходити на харчування представниками таких родин, як Fagaceae, Betulacea, Ericaceae, Salicaceae. До речi, представники Panolis flammea вперше були зафіксовані у фауні досліджуваного району лише під час зборів 2018 р. Це може свідчити про те, що процеси лісовідтворення, що тривають на цих ділянках, формують необхідну кормову базу для цього небезпечного шкідника.

Враховуючи наведене вище, харчування покритонасінними рослинами характерно для 122 із 125 виявлених видів совкоподібних. 3 класом однодольних (Liliopsida) облігатно пов'язано 10 видів, причому 3 із них $€$ широкими олігофагами рослин родини Poaceae: Совка пажитницева темно-бура Tholera cespitis (Denis \& Schiffermüller, 1775); Совка очеретяна двоплямиста (Archanara geminipuncta (Haworth, 1809)); Совка коренева очеретяна (Rhizedra lutosa (Hübner, 1803)). Водночас, $з$ дводольними (Magnoliopsida) облігатно пов'язано 45 видів, причому 2 із них $є$ широкими олігофагами рослин родин Caryophyllaceae (Панемерія роговикова Panemeria tenebrata (Scopoli, 1763)) та Salicaceae (Стрічкарка вербова Catocala electa (Vieweg, 1790)).

Табл. 2. Порівняльні дані для переважаючих родин покритонасінних та видів совкоподібних, що харчуються на найбілышій кількості родин кормових рослин

\begin{tabular}{|c|c|c|c|}
\hline $\begin{array}{c}\text { Родина покритонасінних } \\
\text { кормових рослин }\end{array}$ & $\begin{array}{c}\text { Кількість виявлених видів } \\
\text { совкоподібних }\end{array}$ & Виявлений вид совкоподібних & $\begin{array}{c}\text { Кількість родин } \\
\text { кормових рослин }\end{array}$ \\
\hline Rosaceae & 71 & Acronicta rumicis & 55 \\
\hline Asteraceae & 69 & Helicoverpa armigera & 51 \\
\hline Poaceae & 68 & Lacanobia oleracea & 45 \\
\hline Salicaceae & 64 & Autographa gamma & 39 \\
\hline Polygonaceae & 57 & Phlogophora meticulosa & 38 \\
\hline Fabaceae & 57 & Noctua comes & 38 \\
\hline Betulaceae & 49 & Xestia c-nigrum & 37 \\
\hline Plantaginaceae & 43 & Orthosia gothica & 37 \\
\hline Lamiaceae & 41 & Agrotis ipsilon & 36 \\
\hline Ericaceae & 40 & Euplexia lucipara & 36 \\
\hline
\end{tabular}


Найбільшу кількість видів (табл. 2) виявлено на представниках родин Rosaceae, Asteraceae та Poaceae (71, 69 та 68 виявлених видів відповідно). Отже, проведені дослідження підтверджують тезу про те, що комахи-фітофаги концентруються на найбільших ботанічних родинах (розоцвітих, складноцвітих, злакових тощо), а також про те, що олігофаги надають перевагу родинам рослин 3 найвищим видовим багатством та рослинам-домінантам місцевої флори (Emelyanov, 1966)Окрім цього, важливо зазначити, що всі виявлені види совкоподібних досліджуваного району, які харчуються на найбільшій кількості родин кормових рослин (див. табл. 2), належать до шкідників сільського та лісового господарства. Отже, можна стверджувати, що більшість шкідливих видів за харчовою спеціалізацією $\epsilon$ хортофільними поліфагами 3 дуже широкими трофічними зв'язками.

\section{Висновки:}

1. За період 2011-2018 рр. зібрано 2154 екземпляри комах, що належать до 125 видів совкоподібних, які належать до 3 родин і 24 підродин.

2. Більшість виявлених видів совкоподібних досліджуваного району належить до хортофагів - 65 видів (53\%). Частка дендрофагів та хорто-дендрофагів є приблизно однаковою (22 та 25 \% відповідно).

3. Гусінь совкоподібних досліджуваного району трофічно пов'язана 3105 родинами 3 відділів наземних рослин флори України.

4. Представники відділів папоротеподібних (Polypodiophyta) та голонасінних (Pinophyta) не є характерними кормовими рослинами досліджуваних видів совок. Їх частка незначна: 5,7 та $1 \%$ відповідно.

5. Кормовими рослинами з відділу Polypodiophyta є представники 6 родин.

6. 3 відділу голонасінних як кормові рослини виявлено представників однієї родини - Pinaceae. З'ясовано, що на рослинах родини соснових харчуються 8 видів.

7. Переважаючу частку кормових рослин виявлених видів совкоподібних становлять покритонасінні рослини (Magnoliophyta) - 93,3\%.
8. 3 класом однодольних (Liliopsida) облігатно пов'язано 10 видів; 3 дводольними (Magnoliopsida) облігатно пов'язано 45 видів.

9. Найбільшу кількість видів виявлено на представниках родин Rosaceae, Asteraceae та Poaceae $(71,69$ та 68 виявлених видів відповідно).

10. Більшість шкідливих видів за харчовою спеціалізацією $є$ хортофільними поліфагами 3 дуже широкими трофічними зв'язками.

\section{Перелік використаних джерел}

Barbarich, A. A. (2015). Trophic relationships of the noctuid's larvae (Lepidoptera, Noctuidae sensu lato) in the coniferous-deciduous forest zone of the Upper and Middle Amur Region. A. I. Kurentsov's Annual Memorial Meetings, 26, 150-160. [In Russian].

Derzhinskii, E. A., \& Vogulkina, N. V. (2017). Review of trophic connections of Noctuoidea (Lepidoptera, Noctuoidea) in Belarus. Materialy konferentcii Nauka - obrazovaniiu, proizvodstvu, ekonomike: Materialy XXII (69) regionalnoi nauchno-prakticheskoi konferentcii prepodavatelei, nauchnykh sotrudnikov $i$ aspirantov, (pp. 59-61), February, 9-10, 2017. Vitebsk: VGU imeni P. M. Masherova. [In Russian].

Emelyanov, A. F. (1966). Some features of the distribution of insectoligophages on food plants. Chteniya pamyati N. A. Holodkovskogo, (pp. 28-65). Leningrad: Nauka. [In Russian].

Fibiger, M., Yela, J. L., Zilli, A., Varga, Z., Ronkay, G., \& Ronkay, L. (2011). Check list of the quadrifid Noctuoidea of Europe. In T. Witt, \& L. Ronkay (Eds), Lymantriidae and Arctiidae including Phylogeny and Check List of the Quadrifid Noctuoidea of Europe. Noctuidae Europaeae, 11, 23-44. Soro: Entomol. Press.

Kliuchko, Z. F., Holoborodko, K. K., Pakhomov, O. Ie., \& Afanasieva, V. O. (2011). Biological Diversity of Ukraine. The Dnipropetrovsk region. Moth. (Lepidoptera: Noctuidae). (Vol. 2). Dnipropetrovsk: Vyd-vo Dnipropetr. nats. un-tu, 546 p. [In Ukrainian].

Kovtun, T. I. (2018). The Review of Trophic Connections of Noctuid Moth's Larvae (Lepidoptera: Noctuoidea) in Semi Natural Ecosystems of Zhytomyr Suburban Area. Scientific Bulletin of UNFU, 28(3), 26-29. https://doi.org/10.15421/40280305

Matov, A. Iu., \& Kononenko, V. S. (2012). Trophic connections of the larvae of Noctuoidea of Russia (Lepidoptera, Noctuoidea: Nolidae, Erebidae, Euteliidae, Noctuidae). Vladivostok: Dalnauka, 346 p. [In Russian].

T. I. Kovtun

Zhytomyr National Agroecological University, Zhytomyr, Ukraine

\section{TAXONOMIC COMPOSITION OF HOST PLANTS OF NOCTUID MOTH'S LARVAE (LEPIDOPTERA: NOCTUOIDEA) IN SEMI NATURAL ECOSYSTEMS OF ZHYTOMYR SUBURBAN AREA}

The aim of the study is to analyze the trophic specialization and taxonomic composition of host plants of noctuid moth's larvae (Lepidoptera: Noctuoidea) of semi natural ecosystems Zhytomyr suburban area. Research has been conducted during the field seasons 2011-2018 years. Two research plots which were equipped with permanent items of counting of mouths by light traps have been chosen. The definition of noctuid moths was conducted according to generally accepted international taxonomy. The plot №1 is typical agrocenosis and plot №2 is an example of semi natural biotope where the process of succession continues. As a result of the studies, 2154 specimens of insects belonging to 125 species of noctuid moths, belonging to 3 families and 24 subfamilies, were collected. It has been analyzed the distribution of noctuid moth's larvae in the identified families and subfamilies of Noctuoidea on hortophagous, dendrophagous, horto-dendrophagous as well as the taxonomic composition of host plants. It has been established that the proportion of hortophagous is $53 \%$. The share of dendrophagous and horto-dendrophagous is approximately the same $(22 \%$ and $25 \%$ respectively). I has been revealed the noctuid moth's larvae of the studied area are trophically connected with 105 families of 3 departments of plants of the Ukrainian flora. It has been found that the proportion of representatives of the fern (Polypodiophyta) and gymnosperms (Pinophyta) is insignificant: 5,7\% and $1 \%$ respectively. Host plants from the Polypodiophyta are representatives of 6 families. From the gymnosperms as host plants it has been found members of the family Pinaceae. It has been proven that 93,3 \% of noctuid moth's larvae host plants are angiosperms (Magnoliophyta). The obligatory connection with monocots (Liliopsida) has 10 species; the obligatory connection with dicotyledons (Magnoliopsida) has 45 species. The largest number of species was observed in the representatives of the families Rosaceae, Asteraceae and Poaceae (71, 69 and 68 identified species respectively). It has been established that the majority of pest species are hortophilic polyphages with extensive trophic connections.

Keywords: polyphages; oligophages; hortophagous; dendrophagous; horto-dendrophagous; lichenophagous. 